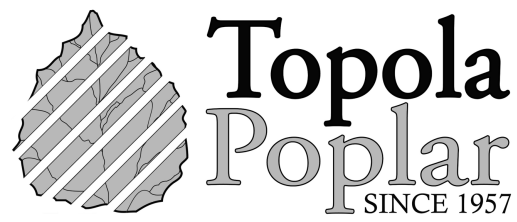

OPEN ACCESS

DOI: $10.5937 /$ topola2006053P

UDC: 582.681.82:632

Original scientific paper

\title{
Predilection of Chaitophorus populeti and Phyllobius oblongus on four clones of white poplar
}

\author{
Leopold Poljaković - Pajnik ${ }^{1 *}$, Milan Drekić ${ }^{1}$, Branislav Kovačević́, Marina Milović ${ }^{1}$, Zoran \\ Novčić1, Verica Vasić1 \\ 1 University of Novi Sad, Institute of Lowland Forestry and Environment, Novi Sad, Serbia \\ * Corresponding author: Leopold Poljaković-Pajnik; E-mail: leopoldpp@uns.ac.rs
}

Received: 9 Dec 2020; Revised: 14 Dec 2020; Accepted: 18 Dec 2020

\begin{abstract}
The predilection of Poplar shoot aphid (Chaitophorus populeti Panzer) and European Snout Beetle (Phyllobius oblongus L.) in the first and second growing season in two experimental plantations. Four white poplar clones were tested: Villafranca, L-100, L-80, and L-12. The first experimental plot was established at the beginning of 2019 and the second in 2020 near Novi Sad (northern Serbia). Predilection of $C$. populeti Panzer was performed on three plants per each of three blocks and every of four clones. Predilection of $P$. oblongus L. was evaluated on all leaves of five shoots on three plants per each of three blocks of every of four clones. According to the results of analysis of variance and Tukey's test for several traits describing intensity of damage and percentage of damaged leaves, there was significant difference between examined clones in prevalence of $P$. oblongus L. Significantly stronger attack was found for clones L-80 and L-12 than on Villafranca and L-100 in both years on plants in their first growing period. The damage from this pest in second growing period could almost not to be detected. In case of $C$. populeti Panzer, the prevalence was assessed according to the percentage of colonized shoots. The differences between examined clones were significant only in first growing period in 2019, where the strongest attack was found on clones Villafranca and L-100, and the weakest on clones L-80 and L-12. Results of the study are particularly important in the context of clones L-12 and L-80 performances evaluation, considering that these clones are still in the experimental phase of testing. Likewise, the intensity of attacks of studied pest species suggests that special attention to their presence and spreading should be paid in the first growing season after plantation establishment.
\end{abstract}

Keywords: Phyllobius oblongus, Chaitophorus populeti, predilection, Populus alba, clones.

\section{Introduction}

Recent introduction of Forest Stewardship Council (FSC) standards in Public Enterprise "Vojvodinašume" largely increased interest in white poplar growing, especially for the purpose of buffer zones establishing. That intensified further research in this species. Beside vegetative propagation, which is one of the main obstacles for further intensification of nursery production and the establishment of plantations of this species (Kovačević et al. 2014; Kovačević and Igić, 2018; Igić et al. 2020; Kovačević et al. 2020), considerable efforts have been made in evaluation of wood physical and anatomical properties (Ištok et al. 2019; Sedlar et al. 2019) and pests predilection to different clones. 
Chaitophorus populeti is apterous aphid-oval shaped dark green to black body. Adult aphids are bright yellow. It is very hairy species. Ovipara, as well as males with or without wings appear in October and November. Individuals of this species colonize preferably young shoot tips, but also on leaf petioles and dorsal side of a leaf-by-leaf veins where they suck plant sap (Blackman and Eastop, 1994). In Serbia, this species primarily found on Populus x euramericana and Populus alba (PoljakovicPajnik et al. 2011). C. populeti is important pest in nurseries and young poplar plantations. The damage caused by this species in white poplar could be considerable. Because of anatomical constitution of leaf and presence of numerous hairs on dorsal leaf side, white poplars retain honeydew much more than black poplar clones, which support growth of sooty molds (Poljaković-Pajnik, 2015.).

The genus of Philobius sp. includes middle-sized weevils of elongated metallic sheen body. Imago appears in spring and at the beginning of summer (Živojinović, 1948). These are very common insects in Europe, Russia, Iran, and Turkey and was introduced North America in 1923 (Tillese et al. 1996). This leaf-eater belongs to polyphagous species, eating leaves of numerous forest and horticultural woody species (Populus, Betula, Quercus, Fagus, Salix) (Tillese et al. 1996), and of the fruits: plums, apples, pears, cherries, peaches, walnuts, hazelnuts (Kereši et al. 2019). It has one generation per year, overwintering as a larva in the soil. The imago occurs in April. It prefers young leaves, biting it along the edge in the form of semicircles or circles over the entire leaf surface. Most of damage is caused by imago (Kereši et al. 2019).

The aim of this work is to evaluate predilection of C. populeti and P. oblongus on four clones of white poplar as well as to evaluate variability and discrimination power of several predilection parameters in young clonal white poplar plantation.

\section{Material and Methods}

The research was conducted in experimental estate of "Kaćka šuma" of Institute of Lowland Forestry and Environment, University of Novi Sad, Serbia, with moderate continental climate. The evaluation of predilection of European Snout Beetle (Phyllobius oblongus L.) and Poplar shoot aphid (Chaitophorus populeti Panzer) was performed in the spring of 2019 and 2020, in four white poplar clones: Villafranca, L-100, L-12 and L-80. The predilection was assessed in two experimental plantations, one established in 2019 and the other 2020, side by side on the same location $\left(45^{\circ} 17^{\prime} 10.84^{\prime \prime} \mathrm{N} ; 1^{\circ} 54^{\prime} 01.71^{\prime \prime}\right.$ E; $74 \mathrm{~m}$ a.s.l.) with spacing $4.25 \times 4.25 \mathrm{~m}$ (1.4 ha of total area). At the site, old black poplar plantation had been previously cut. The plantations were designed as randomized Block system in three repetitions with 27 plants per repetition.

Evaluation of predilection of both pests was performed at the mid of May in both years. In 2019 the evaluation was performed in the first established plantation in its first growing season. In 2020 the evaluation was performed in first established plantation in its second growing season and in second plantation in its first growing season. By this design unique year/growing season treatments were formed, allowing evaluation of the effect of year and the effect of growing season (factor Year/growing season) on the intensity of pests' predilection.

The evaluation of predilection of $P$. oblongus was based on evaluation on all fully developed leaves of three shoots per plant, on three plants per block, in three blocks, by grades regarding percentage of damage on a leaf: $0-0 \%$ of damage, $1-1-10 \%$ of damage, $2-11-25 \%$ of damage, $3-25-$ $60 \%$ of damage, $4-61-99 \%$ of damage, 5 - totally eaten leaf. The following parameters were assessed: $\mathrm{s} 0$ - partition of 0 grade leaves, s1 - partition of 1 grade leaves, s2 - partition of 2 grade leaves, s3 partition of 3 grade leaves, s4 - partition of 4 grade leaves, s5 - partition of 5 grade leaves, s12 - partition of 1 and 2 grade leaves i.e., mildly damaged, s13 - partition of leaves with grades from 1 to 3 i.e. mildly and moderately damaged leaves, s35 - partition of leaves with grades from 3 to 5 i.e. moderately and hardly damaged leaves. All these parameters were transformed by arcsine transformation $(\arcsin \sqrt{X}$ ) to meet normal distribution of frequencies, which is required for application of used statistical tests.

These data were then statistically analyzed by analysis of variance performed by two-way factorial randomized block design analysis of variance model as follows: 
$X_{i j k l}=\mu+c_{i}+y_{j}+c y_{i j}+b_{k}+p_{l(i j k)}+\varepsilon_{m(i j k l)}$

where $\mathrm{X}_{\mathrm{ijkl}}$ stands for measured value, $\mathrm{c}_{\mathrm{i}}$ for $\mathrm{i}^{\text {th }}$ clone, $\mathrm{yj}$ for $\mathrm{j}^{\text {th }}$ year/growing season treatment, $\mathrm{b}_{\mathrm{k}}$ for $\mathrm{k}^{\text {th }}$ block, $\mathrm{pl}_{(\mathrm{ijk})}$ for $\mathrm{l}^{\text {th }}$ plant of $\mathrm{i}^{\text {th }}$ clone, $\mathrm{j}^{\text {th }}$ year/growing season treatment and $\mathrm{k}^{\text {th }}$ block and $\varepsilon_{\mathrm{m}(\mathrm{j} \mathrm{jk})}$ for effect of residual variation. The effect of year describes effect of difference between attacks of Brown leaf weevil at the first growing period of both plantations.

At the same time, the evaluation of predilection of $C$. populeti was performed on all examined clones, on all shoots on the main plants' axis of nine plants. The proportion of colonized shoots on main plant's axis was parameter that was further analyzed. This parameter was transformed by arcsine transformation $(\arcsin \sqrt{X})$ to meet normal distribution of frequencies, which is required for application of used statistical tests.

This parameter was statistically analyzed by two-way factorial randomized block design analysis of variance model as follows:

$X_{i j k l}=\mu+c_{i}+y_{j}+c y_{i j}+b_{k}+\varepsilon_{l(i j k)}$

where $\mathrm{X}_{\mathrm{ijk}}$ stands for measured value, $\mathrm{ci}_{\mathrm{i}}$ for $\mathrm{i}^{\text {th }}$ clone, $\mathrm{y}_{\mathrm{j}}$ for $\mathrm{j}^{\text {th }}$ year/growing season treatment, $c \mathrm{yij}_{\mathrm{ij}}$ for $\mathrm{i}^{\text {th }}$ clone in $j^{\text {th }}$ year/growing season treatment, $b_{k}$ for $k^{\text {th }}$ block and $\varepsilon_{(\text {(ijk) }}$ for effect of residual variation. The effect of treatment describes effect of difference between attacks of Poplar shoot aphid at the first growing period of both plantations, as well as at the second growing period in older plantation (planted in 2019).

Also, at the basis of results of analysis of variance, Tukey's Honestly significant difference test (HSD-test) was performed to test the statistical difference between year/growing season treatments, clones, interaction Year/growing season $\times$ Clone.

\section{Results and discussion}

By long-term studies of researchers in Institute of Lowland Forestry and Environment (ILFE) numerous clones of white poplar characterized by vigorous growth, favorable tree shape, sufficient potential for vegetative propagation and tolerance to biotic and abiotic agents have been selected (Kovačević et al. 2014; Katanić et al. 2015; Kovačević and Igić, 2018; Vuksanović et al. 2019; Igić et al. 2020; Kovačević et al. 2020). As a part of these efforts, the researchers of the ILFE paid considerable attention to the predilection of pests to various clones of poplars, willows, and black locust, as well as to provenances of numerous forest tree species (Poljakovic-Pajnik et al. 1999, 2005, 2007, 2009a, 2009b, 2011, 2016, 2019, Drekić et al. 2008, 2009), as well as to possible application of obtained results to the integral forest protection. Results of these studies suggest the existence of specific pests' predilection to host plants of particular genotypes. The research of predilection toward clones allowed selection and suggestion of pest tolerant white poplar clones, providing genetical basis for protection of future plantations. In case of this study the absence of or tolerable predilection of or C. populeti and P. oblongus would be favorable for a clone in interest.

According to F-test of analysis of variance, variation of all examined parameters of $P$. oblongus were under significant effect of factor Year/growing season except of s5. In this case, there were only two treatments of this factor: first growing season in plantation established in 2019 and the first growing season in the plantation established in 2020. The effect of Clone was significant for most of examined parameters except for s1, s4, and s5, while effect of Interaction was significant only for s0, s1, s3, s45, s35 and s15. The highest F-values for factors Year/growing season and Clone were found for s0, s13 and s15, suggesting high differences between years as well as between clones in these parameters. The effect of Block was significant for all parameters except for s5, suggesting significant differences in conditions between blocks and necessity for introduction of this source of variation in the model (Table 1).

According to Tukey's test, the attack of the pest on plants in the first growing season was stronger in 2019 than in 2020, when the proportion of damaged leaves (s15) was $83 \%$ and $13 \%$, respectively. 
Examined clones by most of parameters were divided in two groups: Villafranca and L-100 in one and L-80 and L-12 in another group. Generally, the attack was stronger on the L-80 and L-12 then on Villafranca and L-100. However, as the significant effect of interaction Year/growing season $\times$ Clone already suggested, there were differences in reaction of examined clones by years. Regarding the number of homogenous groups for this interaction the most precise parameters for description of differences in reaction of clones on years were s0, s1, s3 and s15 that achieved five homogenous groups. So these parameters could be suggested for further study of predilection $P$. oblongus on white poplar clones in further studies. Data for s15 (percentage of damaged leaves), suggest weaker attack of the pest on Villafranca and L-100 than on L-80 and L-12 in 2019 (20-30\% smaller damage). In 2020 Villafranca and L-100 still suffered weaker attack than L-80 and L-12, but difference between two groups of clones was smaller than in $2019(\approx 10 \%)$. There was almost no damage caused by this pest that were detected in 2020 on plants in plantation established in 2019, so they were not included in further statistical analysis. So these plants that were in their second growing season suffered almost no damage by $P$. oblongus, while in the plantation established in 2020 nearby significant damage was found on plants that were in their first growing period. The strong attack in first year could be explained by the fact that plants at the beginning of the first growing period after the establishment of plantation are in relatively poor physiological condition, which lowers their ability to fight the pest's attack by mechanisms of active defence. That could also explain almost the absence of damage caused by this pest in second growing period. So, these results suggest that in the first growing season white poplar plantation should be intensively monitored and treated against this pest if necessary (Table 1).

According to F-test of analysis of variance, variation of percentage of attacked shoots by $C$. populeti were under significant effect of factor Year/growing season. The effect of Clone was not statistically significant but the effect of interaction Year/growing season $\times$ Clone was. The effect of Block was not significant (Table 2).

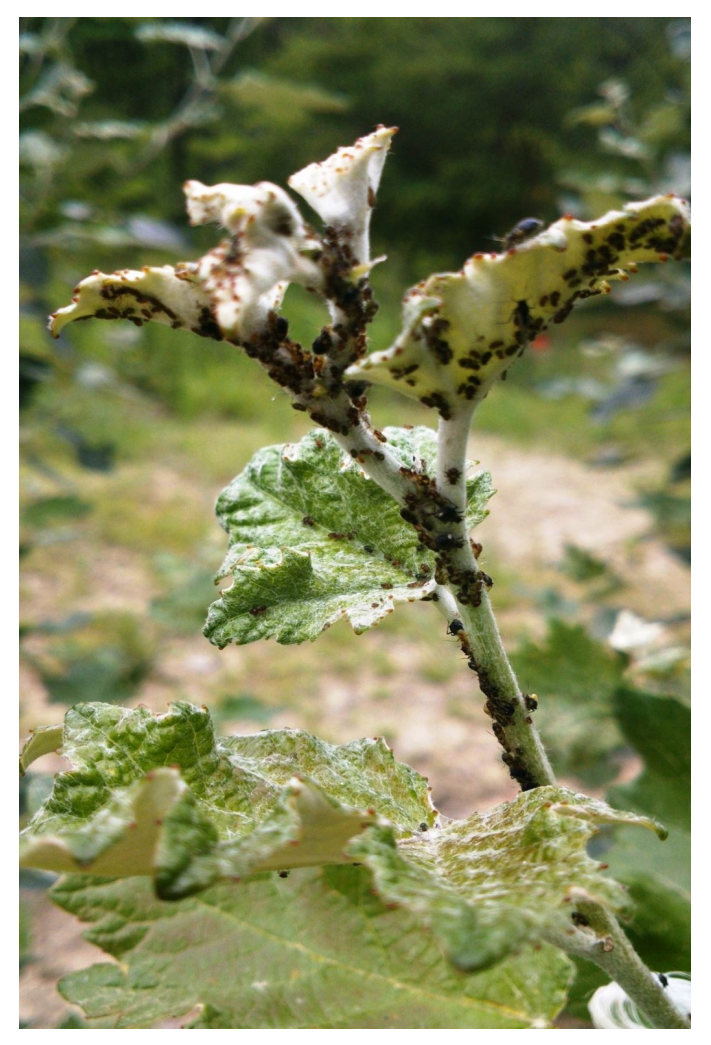

Figure 1. White poplar shoot colonized by C. populeti in 2020 on clone L-80 (photo: Poljaković-Pajnik, L.). 
Table 1. Two-way factorial randomized block design analysis of variance and Tukey's HSD test for examined traits of predilection of Phyllobius oblongus L. on four white poplar clones

\begin{tabular}{|c|c|c|c|c|c|c|c|c|c|c|c|c|}
\hline \multirow{2}{*}{\multicolumn{2}{|c|}{$\begin{array}{c}\begin{array}{c}\text { Sources of } \\
\text { variation }\end{array} \\
\end{array}$}} & \multicolumn{11}{|c|}{ F-test ${ }^{1)}$} \\
\hline & & s0 ${ }^{2)}$ & s1 & s2 & s3 & s4 & s5 & s12 & s13 & s45 & s35 & s15 \\
\hline \multicolumn{2}{|c|}{ Year/growing season (A) } & $1120.00^{* *}$ & $65.11^{* *}$ & $143.07^{* *}$ & $206.97^{* *} 3$ & $36.51^{*}$ & 1.573 & $329.00^{* *}$ & $732.67^{* *}$ & $37.05^{* *}$ & $228.59^{* *}$ & $1079.37^{* *}$ \\
\hline \multicolumn{2}{|c|}{ Clone (B) } & $47.02^{* *}$ & 2.54 & $11.67^{* *}$ & $9.83^{* *}$ & 2.52 & 0.23 & $14.56^{* *}$ & $29.39^{* *}$ & $2.67^{*}$ & $10.77^{* *}$ & $44.45^{* *}$ \\
\hline \multicolumn{2}{|c|}{ Interaction $\mathrm{A} \times \mathrm{B}$} & $3.78^{*}$ & $3.59^{*}$ & 1.25 & $4.46^{* *}$ & 2.52 & 0.23 & 0.29 & 0.62 & $2.67^{*}$ & $6.01^{* *}$ & $3.02^{*}$ \\
\hline \multicolumn{2}{|c|}{ Block (C) } & $7.47^{* *}$ & $6.46^{* *}$ & $5.54^{* *}$ & $7.78^{* *}$ & $3.99^{*}$ & 0.06 & $7.22^{* *}$ & $5.90^{* *}$ & $3.81^{*}$ & $11.26^{* *}$ & $6.71^{* *}$ \\
\hline \multicolumn{2}{|c|}{$\begin{array}{l}\text { Plant within } \\
\mathrm{A} \times \mathrm{B} \times \mathrm{C}\end{array}$} & $2.99^{* *}$ & $1.83^{* *}$ & 1.23 & $3.01^{* *}$ & $1.53^{*}$ & 0.77 & $2.27^{* *}$ & $2.26^{* *}$ & $1.62^{* *}$ & $3.29^{* *}$ & $2.94^{* *}$ \\
\hline \multicolumn{13}{|c|}{ Tukey's HSD test ${ }^{3)}$} \\
\hline Year & Clone & $\mathrm{s} 0(\%)$ & s1(\%) & $\mathrm{s} 2(\%)$ & s3(\%) & $\mathrm{s} 4(\%)$ & s5(\%) & s12(\%) & s13(\%) & $\mathrm{s} 45(\%)$ & s35(\%) & s15(\%) \\
\hline 2019 & & $15.83^{\mathrm{b}}$ & $29.18^{a}$ & $17.54^{\mathrm{a}}$ & $10.76^{\mathrm{a}}$ & $1.34^{a}$ & $0.01^{\mathrm{a}}$ & $57.79^{a}$ & $77.14^{a}$ & $1.43^{\mathrm{a}}$ & $15.12^{\mathrm{b}}$ & $83.13^{a}$ \\
\hline \multirow[t]{5}{*}{2020} & & $87.22^{a}$ & $9.93^{b}$ & $0.99 \mathrm{~b}$ & $0.07^{b}$ & $0.00^{b}$ & $0.00^{a}$ & $12.29 \mathrm{~b}$ & $12.78^{b}$ & $0.00^{b}$ & 0.07 a & $12.78^{b}$ \\
\hline & L-100 & $57.55^{a}$ & $23.27^{a}$ & $4.13^{b}$ & $1.65^{c}$ & $0.03^{b}$ & $0.00^{a}$ & $32.88^{\mathrm{bc}}$ & $41.24^{\mathrm{b}}$ & $0.03^{b}$ & $1.88^{c}$ & $42.45^{\mathrm{b}}$ \\
\hline & Villafranca & $56.66^{a}$ & $17.77^{a}$ & $5.48^{\mathrm{b}}$ & $3.38^{b c}$ & $0.78^{a}$ & $0.00^{a}$ & $29.70^{c}$ & $38.60^{\mathrm{b}}$ & $0.83^{a}$ & $5.57^{b}$ & $43.34^{b}$ \\
\hline & L-12 & $31.00^{b}$ & $17.60^{a}$ & $14.48^{a}$ & $9.12^{a}$ & $1.15^{a}$ & $0.01^{\mathrm{a}}$ & $41.27^{b}$ & $60.52^{a}$ & $1.28^{a}$ & $12.66^{a b}$ & $66.60^{a}$ \\
\hline & L-80 & $25.16^{b}$ & $26.14^{a}$ & $15.08^{a}$ & $6.43 \mathrm{ab}$ & $0.57 \mathrm{ab}$ & 0.00 a & $52.69 a$ & 68.17 a & $0.59 a b$ & $8.76^{a}$ & $72.86^{a}$ \\
\hline 2019 & L-100 & $32.12^{d}$ & $36.12^{a}$ & $8.92 \mathrm{bc}$ & $4.19^{\mathrm{cd}}$ & $0.09^{b}$ & $0.00^{a}$ & $52.45^{\mathrm{b}}$ & $66.04^{\mathrm{b}}$ & $0.09^{b}$ & $4.77^{\mathrm{d}}$ & $67.88^{b}$ \\
\hline 2019 & Villafranca & $29.17^{d}$ & $27.65 \mathrm{abc}$ & $12.01^{b}$ & $8.49 \mathrm{bc}$ & $2.00^{a}$ & $0.01^{\mathrm{a}}$ & $48.73^{\mathrm{b}}$ & $63.60^{\mathrm{b}}$ & $2.11^{a}$ & $13.85^{\mathrm{d}}$ & $70.83^{b}$ \\
\hline 2019 & L-12 & $6.36^{e}$ & $20.90^{\mathrm{bcd}}$ & $26.78^{a}$ & $20.32^{a}$ & $2.94^{\mathrm{a}}$ & $0.02^{a}$ & $58.37 \mathrm{ab}$ & $85.04^{a}$ & $3.26^{\mathrm{a}}$ & $28.12^{\mathrm{d}}$ & $92.72^{a}$ \\
\hline 2019 & L-80 & $4.48^{\mathrm{e}}$ & $32.68 \mathrm{ab}$ & $25.16^{a}$ & $12.83 \mathrm{ab}$ & $1.42 \mathrm{ab}$ & $0.00^{a}$ & $70.75^{a}$ & $89.46^{a}$ & $1.47 \mathrm{ab}$ & $17.85^{\mathrm{cd}}$ & $94.88^{\text {a }}$ \\
\hline 2020 & L-100 & $92.44 \mathrm{ab}$ & $7.00 \mathrm{de}$ & $0.16^{\mathrm{d}}$ & $0.00^{\mathrm{e}}$ & $0.00^{\mathrm{b}}$ & $0.00^{a}$ & $7.56^{\mathrm{d}}$ & $7.56^{\mathrm{d}}$ & $0.00^{b}$ & $0.00^{c}$ & 7.56 de \\
\hline 2020 & Villafranca & 93.92 a & $5.53 \mathrm{e}$ & $0.16^{d}$ & $0.00 \mathrm{e}$ & $0.00^{b}$ & 0.00 a & $6.08^{d}$ & $6.08^{\mathrm{d}}$ & $0.00^{\mathrm{b}}$ & $0.00^{b}$ & $6.08 \mathrm{e}$ \\
\hline 2020 & $\mathrm{~L}-12$ & $83.30^{b c}$ & 12.62 cde & $1.80^{\mathrm{cd}}$ & $0.15^{\mathrm{e}}$ & $0.00^{\mathrm{b}}$ & $0.00^{a}$ & $15.99^{\mathrm{cd}}$ & $16.70^{\mathrm{cd}}$ & $0.00^{b}$ & $0.15^{a b}$ & $16.70 \mathrm{~cd}$ \\
\hline 2020 & L-80 & $75.86^{c}$ & 16.20 bcde & $3.31 \mathrm{bcd}$ & $0.48 \mathrm{de}$ & $0.00^{\mathrm{b}}$ & $0.00^{a}$ & $22.46^{c}$ & $24.14^{c}$ & $0.00^{b}$ & $0.48^{a}$ & $24.14^{c}$ \\
\hline
\end{tabular}

1) Labels for F-test: ${ }^{*}$ - significant at $\mathrm{p}=0.05$; ${ }^{* *}$ - significant at $\mathrm{p}=0.01$

2) Labels of characters: $\mathrm{s} 0$ - partition of 0 grade leaves, $\mathrm{s} 1$ - partition of 1 grade leaves, $\mathrm{s} 2$ - partition of 2 grade leaves, s3 - partition of 3 grade leaves, s4 - partition of 4 grade leaves, s5 - partition of 5 grade leaves, s12 - partition of 1 and 2 grade leaves i.e. mildly damaged, s13 - partition of leaves with grades from 1 to 3 i.e. mildly and moderately damaged leaves, s35 - partition of leaves with grades from 3 to 5 i.e. moderately and hardly damaged leaves.

3) Difference between values with the same letter for the same source of variation is not significant at $\mathrm{p}=0.05$

According to Tukey's test, the difference in damages caused by Poplar shoot aphid in the first growing season in 2019 vs. 2020 was not significant (15-16\% of colonized shoots). However, the colonization in second growing season in 2020 was barely detectable i.e. less than $5 \%$ of shoots were colonized by $C$. populeti. So, these results suggest that the attack in the second growing season in white poplar plantation is much weaker than in the second, so the protection from the attack is much less needed than it is in the first growing season.

In concordance with the results of F-test, the differences between clones were not significant, according to Tukey's test. However, as already suggested by significant effect of interaction Year/growing season $\times$ Clone, the reaction of examined clones on different year/growing season treatments was not the same. Predilection of $C$. populeti differed between clones on plants in the first growing season in plantation established in 2019. In this treatment, percentage of colonized shoots was significantly higher in L-100 and Villafranca, than on L-80 and L-12. The difference between clones in predilection of $C$. populeti in the first growing season in plantation established in 2020 was not 
detectable probably due to relatively weak attack of the pest in 2020 (Figure 1), but differences in prevalence of the pest to different between years should be taken in consideration (Table 2).

Table 2. Two-way factorial randomized block design analysis of variance and Tukey's HSD test for examined traits of predilection of Chaitophorus populeti Panzer on four white poplar clones.

\begin{tabular}{lccccc}
\hline Source of variation & $\begin{array}{c}\text { Sum of } \\
\text { squares }\end{array}$ & $\begin{array}{c}\text { Degree of } \\
\text { freedom }\end{array}$ & $\begin{array}{c}\text { Mean } \\
\text { squares }\end{array}$ & \multicolumn{2}{c}{ F-test ${ }^{1)}$} \\
\hline Treatment (A) & 6276.3 & 2 & 3138.16 & $7.59{ }^{* *}$ \\
Clone (B) & 736.4 & 3 & 245.47 & 0.59 & \\
Interaction A×B & 9171.7 & 6 & 1528.62 & $3.70 \quad * *$ \\
Block & 2267.0 & 3 & 755.67 & 1.83 \\
Residual & 142576.6 & 345 & 413.27 & & \\
\hline
\end{tabular}

\begin{tabular}{llrl}
\hline \multicolumn{2}{c}{ Tukey's HSD test for percentage of shoots attacked by Chaitophorus populeti ${ }^{2)}$} \\
\hline $\begin{array}{c}\text { Growing season/ } \\
\text { year of measurement }\end{array}$ & Clone & $\begin{array}{c}\text { Percentage of } \\
\text { colonized shoots }\end{array}$ \\
\hline $1^{\text {st }}$ season $/ 2019$ & & 15.13 & $\mathrm{a}$ \\
$1^{\text {st }}$ season $/ 2020$ & & 15.81 & $\mathrm{a}$ \\
$2^{\text {nd }}$ season/2020 & L-100 & 4.89 & $\mathrm{~b}$ \\
\hline & Villafranca & 14.00 & $\mathrm{a}$ \\
& L-12 & 15.42 & $\mathrm{a}$ \\
& L-80 & 7.94 & $\mathrm{a}$ \\
& L-100 & 11.34 & $\mathrm{a}$ \\
\hline $1^{\text {st }}$ season/2019 & Villafranca & 26.65 & $\mathrm{a}$ \\
$1^{\text {st }}$ season/2019 & L-12 & 24.31 & $\mathrm{bc}$ \\
$1^{\text {st }}$ season/2019 & L-80 & 5.18 & $\mathrm{~cd}$ \\
$1^{\text {st }}$ season/2019 & L-100 & 6.49 & $\mathrm{bcd}$ \\
$1^{\text {st }}$ season/2020 & Villafranca & 12.45 & abcd \\
$1^{\text {st }}$ season/2020 & L-12 & 11.50 & abcd \\
$1^{\text {st }}$ season/2020 & L-80 & 14.12 & abcd \\
$1^{\text {st }}$ season/2020 & L-100 & 26.63 & abc \\
$2^{\text {nd }}$ season/2020 & Villafranca & 2.87 & $\mathrm{~d}$ \\
$2^{\text {nd }}$ season/2020 & L-12 & 4.17 & abcd \\
$2^{\text {nd }}$ season/2020 & L-80 & 6.40 & abcd \\
$2^{\text {nd }}$ season/2020 & 6.41 & abcd \\
\hline
\end{tabular}

1) Labels for F-test: ${ }^{* *}$ - significant at $\mathrm{p}=0.01$

2) Difference between values with the same letter for the same source of variation is not significant at $\mathrm{p}=0.05$

\section{Acknowledgments}

This work was realized in accordance with the Agreement on performing reporting-diagnostic-forecasting activities in forest protection and other activities of public interest in the field of forest plant health on the territory of AP Vojvodina for the period 2020-2024 (Contract No. 401-00-00058 / 2020-10 of 24 February 2020). The study is supported by the Ministry of Education, Science and Technological Development of the Republic of Serbia (Project No: 451-03-68/2020-14/200197) and Scientific Research Project "Study and improvement of vitality and production potentials of forests in PE Vojvodinašume". 


\section{References}

1. Blackman, R.L., Eastop, V.F. (1994): Aphids on the world's trees: an identification and information guide. CAB International, Wallingford, Oxon. pp. 987.

2. Drekić, M. Pap, P., Poljaković - Pajnik, L., Marković, M., Vasić, V., Kovačević, B. (2008): Stepen preferencije jovinog suplaša (Cryptorrhynchus lapathi L.) prema nekim klonovima crnih topola, IX Savetovanje o zaštiti bilja, 24-28. novembar, Zbornik rezimea, Zlatibor, p. 114.

3. Drekić, M., Kovačević, B., Poljaković Pajnik, L., Pap, P., Marković, M., Vasić, V. (2009): Proučavanje stepena preferencije malog topolinog staklokrilca i jovinog surlaša prema klonovima crnih topola. Topola 183/184: 87-93.

4. Igić D., Borišev M., Vilotić D., Šijačić-Nikolić M., Ćuk M., Ilić M., Kovačević B. (2020): Variability and relationships among rooting characteristics for white poplar hardwood cuttings. Archives of Biological Sciences 72(2): 153-163.

5. Ištok, I., Šefc, B., Sedlar, T., Goršić, E., Mihić , M., Stojnić, S. (2019): Fiber length in clone 'L-12' juvenile wood. Topola 203: 37-43.

6. Katanić M., Kovačević B., Đorđević B., Kebert M., Pilipović A., Klašnja B., Pekeč S. (2015): Nickel phytoremediation potential of white poplar clones grown in vitro. Romanian Biotechnological Letters 20(1): 10085-10096.

7. Kereši T, Konjević A., Popović A. (2019): Posebna entomologija 2. Poljoprivredni fakultet, Novi Sad. 289 str.

8. Kovačević B., Igić D. (2018): Effect of early preparation and slope aspect on survival and growth of white poplar rooted cuttings. Topola 201/202: 117-126.

9. Kovačević B., Igić D., Novčić Z., Orlović S. (2020): Survival and Growth of White Poplar Rooted Cuttings Regarding Term of Planting. Topola 205: 33-46.

10. Kovačević B., Orlović S., Pap P., Katanić M., Dabić S. (2014): Efekat primene praškastih formulacija sa kobalt hloridom i indolbuternom kiselinom na ožiljavanje drvenastih reznica bele topole. Topola 193/194: 117-127.

11. Poljaković-Pajnik, L., Drekić, M., Orlović, S., Kovačević, B. (2007): Predilection research of Chrysomela populi L. (Col. Chrysomelidae) to different clones of willows. IUFRO meeting "Natural enemies and other multi - scale influences on forest insects", 9. - 14. september 2007, Abstract book, Wiena, p. 15.

12. Poljaković-Pajnik L., Drekić M. (2011): Istraživanje predilekcije Phyllonorycter robiniae Clemens i Parectopa robiniella Clemens na ishranu lišćem različitih klonova bagrema. Topola 187/188: 137-144.

13. Poljaković-Pajnik, L., Petrović, O., Vasić V., Vučetić, A., Drekić M. (2011): Biljne vaši roda Chaitophorus na topolama u Srbiji, Biljni lekar 6: 645-656.

14. Poljakovic-Pajnik, L., Obradovic Petrovic, O., Drekic, M., Orlovic, S., Vasic, V., Kovacevic, B., Kacprzyk, M., Nikolic, N. (2016): Aphid feeding effects on physiological parameters of poplar cultivars. Proceedings from VII International Scientific Agriculture Symposium "Agrosym 2016", 6-9 October, Jahorina, Bosnia and Herzegovina: 2848-2855.

15. Poljaković-Pajnik, L., Drekić, M., Kovačević, B., Stanković-Neđić, M., Stojnić, S., Orlović, S. (2019): Host preference of Myzus cerasi (Fabricius, 1775) to half-sib lines of Prunus avium L. from six populations assessed in the nursery trial. Topola 203: 87-94.

16. Poljaković-Pajnik, L., Orlović, S. (2009): Physiological response of different poplar clones to aphid colonization. 8th International Symposium on Aphids. Book of abstracts. 8-12 June 2009, Catania (Italy), p. 176.

17. Poljaković-Pajnik, L., Orlović, S., Vasić, V., Drekić, M. (2009): Aphid influence to contest of photosyntetic pigments of different poplar cultivars. Proceedings from International Conference "Forestry in achieving millennium goals, Held of the 50th anniversary of foundation of Institute of Lowland Forestry and Environment, November 13-15, Novi Sad, Serbia: $277-282$. 
18. Poljaković-Pajnik, L. (2015): Diverzitet biljnih vašiju drveća i žbunja. Doktorska disertacija. Univerzitet u Beogradu, Poljoprivredni fakultet, Zemun - Beograd. 197 pp.

19. Poljaković-Pajnik, L., Drekić, M., Kovačević, B., Vasić, V., Avramović, G. (2005): Istraživanje predilekcije Leucoptera sinuella Rtti (Lepidoptera: Leucopteridae) na ishranu lišćem različitih klonova crnih topola. Topola 175/176: 39-48.

20. Poljaković-Pajnik, L., Orlović, S., Jodal, I. (1999): Istraživanje predilekcije Chrysomela populi L. (Col. Chrysomelidae) na ishranu lišćem nekih klonova crnih topola. Topola 163/164: 41-46.

21. Popović, V., Lučić, A., Rakonjac, Lj. (2017): Stanje šumskih genetičkih resursa u Srbiji i pregled aktivnosti na njihovoj konzervaciji. Selekcija i semenarstvo 23: 1-13.

22. Sedlar, T., Ištok, I., Orešković, G., Stojnić, S., Goršić, E., Šefc, B. (2019): Physical properties of wood in white poplar clone 'L-12' grown in Republic of Croatia and Serbia. Topola 203: 45-51.

23. Tillese, V., Nef, L., Charles, J., Hopkin, A., Augustin, S. (1996): Damaging poplar insects Internationally important species. Available online at: http://foris.fao.org/static/pdf/ipc/damaging_poplar_insects_eBook.pdf (accessed Dec 12, 2020).

24. Vuksanović, V., Kovačević, B., Kebert, M., Katanić, M., Pavlović, L., Kesić, L., Orlović, S. (2019): Clone specificity of white poplar (Populus alba L.) acidity tolerance in vitro. Fresenius Environmental Bulletin 28(11): 8307-8313.

25. Živojinović, S. (1948): Šumarska entomologija. Naučna knjiga, Beograd. 352 pp. 